\title{
SEX WORKERS' RELIGIOSITY AND FAITH IN GOD: Case Study on “Ayam Kampus” in East Java, Indonesia
}

\author{
Syamsul Rijal \\ UIN Ar-Raniry Banda Aceh \\ literasi.syamsulrijal@ar-raniry.ac \\ Umiarso \\ Universitas Muhammadiyah Malang \\ umiarso@umm.ac.id
}

\section{Abstract}

Prostitution is often called to be a social disease that is far from anchoring the values of religiousness, especially diversity. It is normal if the stigma of tilting towards sex workers arises from insults, mocks, until the behavior of ignorance shown by the clergy. Even though sex workers are outside the circle of prostitution, they are "giddy" looking for life's meaning in the form of religious feelings in which there is a sense of divinity. Therefore, this article tries to understand the reality of religion - in which there are also emerging of sex workers. The reality is analyzed using the theory of dramaturgy which divides prostitution into the front stage (the practice of prostitution) and the rear stage (the privacy of sex workers). This article uses a qualitative approach to the type of phenomenology that portrays the practice of ayam kampus prostitution in East Java. Data collection used in-depth interviews and participant observation; Data analysis used the interactive models of Miles and Hubermann. This research found that the front stage of the practice of prostitution has never been friendly with the presence of God, especially to express its diversity. But, on the back stage, they can expose themselves in their religiosity and divinity with full serenity and appreciation. The conclusions of this research is the religiosity practiced by sex workers is separated from the normative symbol of religion, while God is immersed tightly in their soul and God is present in the most subjective and impersonal form in him. 


\section{Abstrak}

Pelacuran seringkali dikatakan sebagai penyakit sosial yang jauh dari jangkar nilai-nilai keberagamaan terlebih kebertuhanan. Lazim apabila stigma miring terhadap pelacur muncul mulai dari cercaan, hinaan, hingga perilaku pengacuhan yang diperlihatkan oleh para agamawan. Padahal pelacur ketika berada di luar lingkaran praktek prostitusi, ia "gamang" mencari makna kehidupan berupa perasaan keberagamaan yang di dalamnya terdapat rasa kebertuhanan. Karenanya, artikel ini mencoba untuk memahami realitas keberagamaan -yang di dalamnya juga muncul kebertuhanan- pelacur. Realitas tersebut dianalisis menggunakan teori dramaturgi yang membagi prostitusi menjadi panggung depan (praktek prostitusi) dan panggung belakang (privasi pelacur). Artikel ini menggunakan pendekatan kualitatif dengan jenis fenomenologi yang memotret praktik prostitusi ayam kampus di Jawa Timur. Sedangkan untuk pengumpulan data menggunakan wawancara mendalam dan observasi partisipan; analisa data menggunakan model interaktif Miles dan Hubermann. Riset ini menemukan bahwa panggung depan praktik prostitusi tidak pernah ramah dengan kehadiran Tuhan, terlebih untuk mengekspresikan keberagamaannya. Tetapi, di panggung belakang, mereka bisa menelanjangi dirinya dalam keberagamaan dan kebertuhanannya dengan penuh ketentraman dan penghayatan. Sedangkan kesimpulan dari riset ini, keberagamaan yang dipraktekkan pelacur lepas dari simbol normatif agama, sedangkan Tuhan sendiri dibenamkan rapat-rapat dalam jiwanya dan Ia hadir dalam bentuk yang paling subjektif dan impersonal dalam dirinya.

Keywords: Sex Workers, Religiosity, and Divine Perception

\section{A. Introduction}

God, religion, and sex workers are three warm entities to be appointed as academic discourses, and have even spawned centuries of debate. These three entities practically have a strong correlation until prostitution appears in the name of sacred prostitutes -or writer calls it with the sex workers of God. One of the examples is Hetaerae who is intelligent, graceful, and honorable in Ancient Greece, Meretrice who was despised and forced to wear a wig, walked erratically, and became a vagrant in the corner of the city in Roman society, temple maidens who offered their virginity in religious ceremonies of ancient societies, Mary Magdalena who lived during the time of Jesus Christ as told by the Gospel, Firdaus in Arabia who chose to be a free sex workers rather than being an enslaved wife. ${ }^{1}$ Various forms of stigma are tilted starting from insults, mocks, until the behavior of ignorance shown by the religionists

${ }^{1}$ See Bene Ratih, "Perempuan dan Teater," in Teori-Teori Kebudayaan, ed. Mudji Sutrisno and Hendar Putranto (Yogyakarta: Kanisius, 2005), 341.; See also Melissa Hope Ditmore, ed., Melissa Hope Ditmore (Edit.), Encyclopedia of Prostitution and Sex Work, Vol. 2 
directed towards them. Whereas in this context there was an active role for men who participated in establishing prostitution practices but were never discussed. This is caused by the interpretation of normative-doctrinal texts of religion which are misused to look at and overtake female sexuality -even in the Christian tradition Jesus said one of them is to reduce pressure from prostitution, ${ }^{2}$ plus the existence of acts of public violence against women due to the flow of urbanization and industrialization which tends to exploit women. Consequently, the attitude of women defying in the sexual dimension -which becomes the root of the polemic, ${ }^{3}$ encourages the potential of sex as a gift from God to be manipulated in the form of commercialization that is separated from religious values. In fact, sex that is separated from religious values (god) is sex that has a sweet taste but crippling and destructive. ${ }^{4}$

Sex itself is a human potential that is able to deliver to "the greatest self-disclosure" from God. ${ }^{5}$ It means sex can push people towards religious perfection (makrifah) which is revealed in the experience of uniting feeling (pleasure). Moreover, this activity is closely related to the reproduction of the human species itself; ${ }^{6}$ through the nature of human life created in pairs (QS. Adz-Dzariyaat: 49). Therefore, sexual activity is a natural and normal part of God's good creation; ${ }^{7}$ and not necessarily far from the "presence of God" as a transcendental entity in human life. Finally it is undeniable, even though on the dimensions of sexuality -reading prostitution, humans will continue to look for the meaning of their lives. In the end, as Eliade said, a process of

(O-Z), (London: Greenwood Press, 2006), 388., vol. 2 (London: Greenwood Press, 2006), p. 388.

${ }^{2}$ Vern S. Poythress, Reading The Word of God In The Presence of God: A Handbook For Biblical Interpretation, (Illonis: Crossway, 2006).

${ }^{3}$ Marissa Moury, “London's Bridewell: Violence, Prostitution, and Questions of Evidence," in Violence, Politics, and Gender in Early Modern England, ed. Joseph P. Ward (New York: Palgrave Macmillan, 2008), p. 217.

${ }^{4}$ Johann Christoph Arnold, Sex, God \& Marriage (Farmington: The Bruderhof Foundation, Inc., 2002), p. 54.

${ }^{5}$ Sachiko Murata, The Tao of Islam: Kitab Rujukan tentang Relasi Gender dalam Kosmologi dan Teologi Islam, trans. Rahmani Astuti and M.S. Nasrullah ((Bandung: Mizan, 2000), p. 249.

${ }^{6}$ Gwen J. Broude, "Sexual Attitudes and Practice," in Encyclopedia of Sex and Gender: Men and Women in the World's Cultures, ed. Carol R. Ember and Melvin Ember (New York: Plenum Publishers, 2003), p. 177.

${ }^{7}$ Sachiko Murata, The Tao of Islam, n.d., p. 231. 
sacredness emerged in man or the ordination of human life itself; ${ }^{8}$ which would be a mysterious personal power, as Sigmund Freud's view. ${ }^{9}$ It means the dialectical process of the personal human being with his God can occur in the field of very broad life and humanitarian activities. ${ }^{10}$ Any profession can be used to achieve spiritual experience, which ultimately -read the prostitutescan lead to an understanding of perceptions of God. Moreover, as Ibn 'Arabi believes, there is no evil in creating everything in the universe (humans); ${ }^{11}$ since the origin of the incident, humans have the potential for straight religion (tauhid). ${ }^{12}$

The fact is that there are some people who see the reality of prostitution as inseparable from religious values or divinity. As a research conducted by Nur Syam about "Agama Pelacur: Dramaturgi Transedental" which breaks down the phenomenon of prostitution in Surabaya through the theory of dramaturgy. This research states that prostitution is marginalized as a result of incomplete reading of perpetrators (sex workers). Apparently, sex workers -on the back stage- are able to present themselves as "servants" of God and social beings, but this is reduced because it is read lame by just looking at the side of the front stage. ${ }^{13}$ There was a research of Arun Kumar Acharya on "Impact of Cultural and Religious Practices of Prostitution on the Trafficking of Women in India". This research found that the practice of human trafficking, including prostitution, is not free from culture and religion. ${ }^{14}$ There was also a critical description from Soffa Ihsan about "In The Name of Sex: Santri, Dunia Gender, and Kitab Kuning". This analysis outlines critically about the struggle of religious values (Islam) with social reality including prostitution.

${ }^{8}$ Mircea Eliade, Sakral dan Profan, trans. Nuwanto (Yogyakarta: Fajar Pustaka Baru, 2002), p. 7.

9 John H. Hick, Philosophy of Religion (New Jersey: Prentice-Hall, Inc., 1990), p. 33; for more detail James J. DiCenso, The Other Freud: Religion, Culture and Psychoanalysis (London: Routledge, 1999).

${ }^{10}$ Musa Asy’arie, Filsafat Islam: Sunnah Nabi Dalam Berpikir (Yogyakarta: LESFI, 2001), p. 173.

${ }^{11}$ Abdullah Saeed, Islamic Thought: An Introduction (London: Routledge, 2006), p. 81.

${ }^{12}$ M. Quraish Shihab, Wawasan al-Qur'an: Tafsir Maudhu'i atas Pelbagai Persoalan Umat (Bandung: Mizan, 2004), p. 284.

${ }^{13}$ Nur Syam, Agama Pelacur: Dramaturgi Transendental (Yogyakarta: LKiS, 2010).

${ }^{14}$ Arun Kumar Acharya, "Impact of Cultural and Religious Practices of Prostitution on the Trafficking of Women in India," Trayectorias, Vol. 14, (2011): p. 95-114. 
However, a woman's body is exploited to get the peak of sexual satisfaction and enjoyment or even the fulfillment of economic or political desires. ${ }^{15} \mathrm{Or}$ Darrel W. Ray's writings in "Sex \& God: How Religion Distorts Sexuality" which reveal prostitution and religion are seen as two entities that can be linked. As happened in several world civilizations, for example in Greece there were several statesmen who used tax money from brothels to finance a temple and also in certain places and times sacred prostitutes became part of religious rituals. Even in Rome, although in terms of religion the talk of sex was rather closed, but prostitution was a common part of Roman society. ${ }^{16}$

On the other hand, there are also those who associate religion and prostitutes with boundary lines, such as Paula Bartley's research on "Prostitution: Prevention and Reform in England, 1860-1914". He studies prostitution from the aspect of morality, so that this research states that prostitution is a mental disability and the community needs to seek liberation from the practice. ${ }^{17}$ Muhammad Latif Fauzi's research on "Religious Symbolism and Democracy Encauntered: A case of Bylaw of Bantul Prostitution" also explicitly and formally-legal states that the practice of prostitution is a prohibited social practice. Because it results in a standard order of religious and social values that is damaged and can degrade women's dignity. ${ }^{18}$ Although, as ritis study Stephen Garton in the "Histories of Sexuality: Antiquity to Sexual Revolution" considers that the history of women's sexuality - prostitution - has reshaped the era of trafficking in women's bodies as a form of work commodity, thus pushing the stage of sexuality. ${ }^{19}$

Based on previous facts, this article tries to understand the reality of religion - in which there are also emerging sex workers. Realities that are constructed from the experience of their social reality are interpreted according to their own understanding. However, the reality was analyzed

${ }^{15}$ Soffa Ihsan, In The Name of Sex: Santri, Dunia Kelamin, Dan Kitab Kuning (Surabaya: JP Books, 2004).

${ }^{16}$ Darrel W. Ray, Sex \& God: How Religion Distorts Sexuality (Kansas: IPC Press, 2012), p. 141-143.

${ }^{17}$ Paula Bartley, Prostitution: Prevention and Reform in England, 1860-1914 (London: Routledge, 2000).

${ }^{18}$ Muhammad Latif Fauzi, "Religious Symbolism and Democracy Encauntered: A case of Prostitution Bylaw of Bantul," al-Jami'ah, Vol. 50, No. 1, (2012), p. 87-118.

${ }^{19}$ Stephen Garton, Histories of Sexuality: Antiquity to Sexual Revolution (London: Equinox Publishing Ltd., 2006), p. 9. 
using Erving Goffman's dramaturgy theory, so that the prostitution area was divided into two stages, namely the practice of prostitution (front stage) and the privacy of prostitutes (backstage). Therefore, this article focuses on the religious and godly side (God's perception) of sex workers. The results of the meaning of reality are expected to be able to pre-empt the prejudice which has been framing prostitutes with bad stigma without looking at the very privacy side, so that an egalitarian view on the basis of divine unity will be created.

This study uses a qualitative approach to the type of phenomenology. This research portrays the diversity and security of covert prostitutes commonly referred to as "Ayam Kampus". The total respondents were seven people and were selected purposively from four universities in the East Java region. Determination of respondents based on considerations: first, those who have a religious education background; and second, he also has a strong religious (cultural) tradition in their families. Data were collected using indepth interviews and participant observation; Data were analyzed using the interactive models of Miles and Hubermann.

\section{B. God, Religion, and Human}

Mercia Eliade built a theory about sacred and profane based on the argument that religious human beings are subjects who are able to find many modalities of the sacred namely being; because for religious humans, nature is never only something "natural" but full of religious values. ${ }^{20}$ based on this view, humans are able to build a sense of religiosity through a dialectical process between themselves and the reality that surrounds them as like Ibrahim AS when did wandering in search of his God who continued to struggle with the reality. Finally he found the "truth above the truth" known as the Haniffiyyah doctrine in which the concept of the One God was known. ${ }^{21}$ It means he was able to carry out religious reconstruction towards the one faith in God; Max Weber called it "strict monothoism". ${ }^{22}$ Therefore, religiosity is very dependent

\footnotetext{
${ }^{20}$ Mircea Eliade, Sakral Dan Profan, p. 117.

${ }^{21}$ Mu'arif, Monoteisme Samawi Autentik: Dialektika Iman Dalam Sejarah Peradaban
} Yahudi, Kristen, Dan Islam, (Yogyakarta: IRCiSoD, 2018), p. 72-85. compare with Harold Thompson, Abraham: From Faith to Faith (Bloomington: WestBow Press, 2017) see too; Edir Macedo, The Faith of Abraham: Self-Denial, Sacrifice, Trust and Total Surrender (Rio de Janeiro, 2018).

${ }^{22}$ Max Weber, The Sociology of Religion, trans. oleh Ephraim Fischoff (Boston: Beacon Press, 1964), p. 138. 
on the awareness of human spirituality itself which encourages and realizes sacredness in every variant of their lives including in the context of forming perceptions about God as the highest being. Through this concept, humans will totally surrender to "the highest (God)" as a manifestation of their faith in God; Izutsu said that it is as a natural predisposition (fitrah) where God determines his will (fatara) for humans. ${ }^{23}$

Interestingly, the actualization of the awareness of diversity and human godliness -whatever the profession is- has implications for the series of perceptions and conceptions of religion and God, because the substance of the depth of actuality -read: the fullness of experience- is definiteness; when it is being a definitive entity means that all elements of a complex whole contribution to a particular effect, ignoring other effects. In this creative process, as Whitehead said, there is a process of "exclusion" and at the same time the process of "merging" (inclusion). ${ }^{24}$ Therefore, human religiosity and faith in God cannot be limited by the worldly dimensions that frame their lives. It means there is a permanent correlation between the dimensions of divinity and humanity which forms personal definitive-singularities, namely religion. Although, there are those who place more importance on the position of religion in the framework of social functions by not agreeing that religion is constantly associated with gods, with superhuman strength or experience. ${ }^{25}$

"Infidelity" between human consciousness and social reality needs to be raised by the meaning of religiosity and its integrity. It can be included in the scope of the social reality of religious sex workers, because she who has been claimed as an entity is frightening, disgusting, and far from religious values. So, it should be realized, the dialectical process of sex workers' consciousness with transcendental reality commonly called experience is the core of religion. As Abraham's grandson, Ya'qub AS, struggled all night with an angel and changed, obtained the name "Israel", "prince of God". ${ }^{26}$ It means that experience is a form

${ }^{23}$ Toshihiko Izutsu, Relasi Tuhan Dan Manusia: Pendekatan Semantik Terhadap AlQur'an, trans. Agus Fahri Husein (Yogyakarta: Tiara Wacana Yogya, 2003), p. 119.

${ }^{24}$ Alfred North Whitehead, Mencari Tuhan Sepanjang Zaman: Dari Agama-Kesukuan hingga Agama-Universal, trans. oleh Alois Agus Nugroho (Bandung: Mizan, 2009), p. 121.

${ }^{25}$ Tyler T. Robert, Spiritualitas Postreligius: Eksplorasi Hermeneutis Transfigurasi Agama dalam Praksis Fiilsafat Nietzsche, trans. oleh M. Khatarina (Yogyakarta: Qalam, 2002), p. 13.

${ }^{26}$ Louis P. Pojman dan Michael Rea, ed., Philosophy of Religion: An Anthology, (Canada: Thomson Wadsworth, 2008), p. 93. 
of representation of human consciousness on the transcendental dimension that is "present" in their lives. However, the transcendental dimension position has its substance as the highest reality; as the highest worship entity. ${ }^{27}$ Therefore, God is regarded as a function in the world that makes human wills directed at realized goals that are impartial to human interests. ${ }^{28}$ If so, following the concept of human needs, Godhead is part of the basic human needs in life, besides biological and social needs absolutely. It is an integrative need, which is a variety of human needs in fulfilling his spiritual desires. ${ }^{29}$ Normally in a factual context, God is considered one of the fundamental aspects of religion; ${ }^{30}$ therefore, It has an important role in the development of human morality. ${ }^{31}$

Religion places itself as a bearer of immanent doctrine to provide certainty for the safety of human life. The implication is that humans get dependence on religion which is believed to be able to provide solutions and "cure" the problems of their lives. It is no exaggeration if Chad Meister proposes the thesis that religion involves a system of beliefs and practices that are primarily centered around transcendent reality, both personal and impersonal, which provides the main meaning and purpose of life. ${ }^{32}$ Therefore William A. Haviland gives limits, religion as beliefs and behavioral patterns that are sought by humans to deal with urgent problems that cannot be solved using known technology and organizational techniques. ${ }^{33}$

\section{Sex Workers Religiosity}

Social reality that upholds the patriarchal system places sex workers in the lowest strata exploited by the nature of humanity. "As if" this profession

${ }^{27}$ Robert S. Ellwood dan Gregory D. Alles, The Encyclopedia of World Religions, (New York: Facts on File, Inc., 2007), p. 176.

${ }^{28}$ Whitehead, Mencari Tuhan Sepanjang Zaman: Dari Agama-Kesukuan hingga Agama-Universal, p. 180.

${ }^{29}$ Syam, Agama Pelacur: Dramaturgi Transendental, p. 1.

${ }^{30}$ Eviatar Zerubavel, "The Five Pillars of Essentialism: Reification and the Social Construction of an Objective Reality," Cultural Sociology, Vol, 10, no. 1, (2016), p. 69-76.

${ }^{31}$ Raymond J. VanArragon, Key Terms in Philosophy of Religion (London: Continuum, 2010), p. 22.

${ }^{32}$ Chad Meister, Introducing Philosophy of Religion, (London: Routledge, 2009), p. 6.

${ }^{33}$ William A. Haviland, Antropologi, trans. oleh RG. Soekadijo (Jakarta: Erlangga, 1993), p. 193. 
is "devoted" to humans who are marginalized from power struggles in the social, cultural, political and economic domains or even religious values. When he experiences psychological trauma, it is actually the result of being alienated from the nature of humanity. The action that he lives is essentially a manifestation of compulsion for themselves as a result of the absence of safe, comfortable, and able choices to actualize themselves. Not only that, the religiosity of sex workers is also alienated until institutions. Religious doctrines and social norms do not provide value and meaning as religious reality. The more the sex workers are exploited in the name of religion, the more they are alienated from humanity as a godly and religious being. However, when they realized that they were alienated because of the existing system, they began to worry, be anxious, afraid and longed for the presence of God in their life. In this realm, sex workers have two opposite sides; in one side they need to let go of their religious attributes when they incarnate with their profession and on the other hand burst of their religious feelings.

Thus, the awareness of religious sex workers is formed from the results of the dialectical process between theirselves and social reality. This process also gave birth to an understanding of the sex workers who led them to become more distant from the religious values they believed in; or vice versa it will make it easier to realize and apply religious values in their lives. This framework created a theological-dogmatic order of prostitutes in which there are concepts and perceptions about God that they believe. As one of the sex workers stated when interviewed by researcher that:

"It feels like I really want to be like before,when carrying out worship such as during childhood, never leave five daily prayers. I was taught how to pray well, recite the appropriate lengths of reciting verses (according to tajwid, pen.) and jokewith friends when praying made the atmosphere cheerful. Pak kiai often gives advice to be a child who is useful to others and a religion that later gets the pleasure of Allah and in the Hereafter will get a reward in the form of heaven. If you become a rebellious child, like to lie, steal, you will go to hell. Mas... I want to be like my carefree childhood. I don't want to feel like this, Mas... who only gets insulted by people and even sins (sometimes she wipes her tears, pen.)".

In the dialectical process between self and social reality, they are based on the ratio as the main base. Just like Ibn Rushd when building the argument for divine philosophy, reason is placed as the main medium; It is only natural that the built-in philosophy of divinity is based on logic and rational premises. Functional reason directs to look for causes that occur in natural events and 
social phenomena. ${ }^{34}$ Therefore, through its logical role it is not uncommon for social reality to be interpreted as a fact that has religious values that lead to the perfection of their divinity.

Interestingly in the process of "reading" social reality, sex workers are able to guide themselves to stabilize their psychic into human beings who are honest and useful to others. In social reality, especially in the world of prostitution which is smeared with sin, sex workers are able to be proportional by taking lessons from the dynamics of the behavior of the sins that occur or that they do. Every single life of sin is intended to provide benefits to their soul to be more mature and wise in addressing the problems of life. This is reflected in their adult attitudes as a sex worker's statement to researchers that:

"God made us to be honest, Mas... but something that makes it strange is human beings who are only able to judge without looking deeperly. Just try to see a lot of respected officials, neat, and pretentious even though they shoplifted public money. The point is that bad people are thought to be good people and good people are thought to be bad... the important thing is to take lessons, Mas. Because we do not know which ones must be justified and which are to blame. Let God only judge and decide... ya, mas (she jokingly stated, pen.) There is a fee in this interview, $y a$... (while laughing, pen.)".

Therefore, a sex worker's psychic who shows "anxiety" and "submission" to the practice of prostitution which she now lives is a form of relation between worldly behavior and divine reality. She assumed, when the dynamics of life that he lived was a mistake that was not in accordance with religion, then she would bring "consequences" at this time especially in the hereafter. Therefore, they tend to submit to God all the consequences that will be accepted. This can be interpreted as a religious census of sex workers that makes them feel and experience worldly things as a clue to the "divine" dimension. It is the experience that builds ideas about religiosity, especially the reality of divinity in sex workers. Through this experience, humans intuitively and affectively are able to see the mystery of "transcendental reality" (God) through the medium of appearance of profanistic symbols, ${ }^{35}$ as in their statement:

"Mas, I carry out religious orders solely I hope God forgives me. I'm sure God knows what I feel and why I stay with this life. I am sincere... if someday I have

${ }^{34}$ Mohammad Erfan, Menalar Tuhan Filosof Islam: Kajian Kritis Konsep Teologi Ibnu Rusyd (Yogyakarta: Kerjasama LK3 \& Aswaja Pressindo, 2011), p. 186; also see M. Amin Abdullah, Islamic Studies di Perguruan Tinggi: Pendekatan Integratif-Interkonektif, (Yogyakarta: Pustaka Pelajar, 2006), p. 212-13.

${ }^{35}$ Rudolf Otto, The Idea of The Holy (England: Penguin Books, 1989), p. 143-48. 
to accept revenge from my actions (go to hell, Pen.). But I really hope that what I have done gets a balance that is in accordance with my sincerity, Mas."

This religious dynamics leads sex workers to the essence of ultimate truth without reducing the integrality between themselves and God. It is natural that the dynamics of religious sex workers tend to have deep theological and philosophical credibility. In contrast to conditions that reduce "the sacred" tend to be marked by the loss of intuition which is seen as the only means of adequacy to understand the soul and meaning of humanity itself. Actually in the Islamic tradition itself this dynamic is seen in the belief system of the Prophet Ibrahim who "sought" the truth of divinity through worldly symbols. M. Dawam Raharjo provides a distinguishing feature between the prophet Ibrahim and the previous prophets, among others: First, he gained an understanding of God through a process of thought struggle from a young age by means of observation; Secondly he spread and championed his beliefs to various nations; and Third, he is a person who is tested by various commands and prohibitions of Allah, and therefore he was chosen as the leader of mankind, as stated in the Qur'an. ${ }^{36}$ M. Quraish Shihab also stated, Ibrahim found and fostered his faith through search and spiritual experiences that he passed and this - in Qur'ani - proved not only in his discovery of the oneness of God exclaiming all the worlds, but also in the belief about the resurrection day. ${ }^{37}$

Therefore, religion is "the relation of man to something else, which is not human"; "Meeting humans with transcendental reality". It means the core of sex workers' religion is the dialectic between the sacred and the profane which is full of hierofani - "the sacred" manifests itself in worldly symbols. Humans are religious, even in this context sex workers will try to live in a sacred world or in the midst of sacred symbols even if that is only meaning. "The sacred" is a force for religious people; and it is actually the same as the condition for being. The conflict between "the sacred" and "the profane" for religious people can be balanced with "real" and "not real". The business of religious life is the same as "being", taking part in reality, equipping oneself with strength. ${ }^{38}$

${ }^{36}$ M. Dawam Rahardjo, Ensiklopedi al-Qur'an: Tafsir Sosial Berdasarkan KonsepKonsep Kunci (Jakarta: Paramadina, 2002), p. 78.

${ }^{37}$ Shihab, Wawasan al-Qur'an: Tafsir Maudhu'i atas Pelbagai Persoalan Umat, 21.

${ }^{38}$ Irfan Noor, Agama Sebagai Universum Simbolik: Kajian Filosofis Pemikiran Peter L. Berger (Yogyakarta: Pustaka Prisma, 2011), p. 169-70. 
Interestingly, sex workers' inner turmoil turned out to create contradictory feelings, namely the feeling of being anxious (fear) and hope (dependence) that was high towards the reality outside of him. Feelings of anxiety and fear of the shadow of sin due to transactional behavior of "sexual pleasure" that violates religious prohibitions not only have implications for the clash of conscience, but also on the behavior of sexual relations with customers that they do with disgust and tends to act "rude" with the aim of speeding up his duty. On the other hand, due to feelings of anxiety and fear of the behavior of violations of religion ( $\sin$ ), sex workers really hope to be able to get God's forgiveness and depend on God's great hope. For sex workers, God is expected to be the only reality for a place depending on all their hopes, because they cannot get that space from a social environment that sees themselves as a person who has no moral, disgusting, and sinful. In this context they state that:

"...God is the only place to hope and complain. I have faith that God is allseeing and knows best what his servant wants. How can I avoid God's infinite omniscience ... .

As a result, sex workers' passivity was formed against the stretch of social dynamics which placed him in the "lowest" strata. However, they believed profane reality could not be separated from the big framework of transcendental reality. Therefore, every time - sometimes - carrying out God's commands as other people carry them out like prayer or fasting. Although they are perfunctory, they feel the calm and tranquility of these religious behaviors. From this religious genealogical structure, a feeling of "total dependence" arises on transcendental reality. The implication is that he gave his whole life to God; and indeed, humans must be submissive and obedient to the divine self (QS. Yunus: 90-91). This feeling arises because sex workers' experience a feeling of mystery and fear of the "sacred". These two feelings can be experienced to their highest peak, namely the state of ecstasy in a mystical experience; Rudolf Otto termed this situation as a structure of numinous. ${ }^{39}$ However, this form of submission is a partial spirit of religious prostitution, although it is not massive and systemic to carry out formal religious behavior, sex workers continue to practice formal religious attitudes such as loving the poor, orphans or commonly referred to as social piety. If so, sex workers cannot be claimed to

\footnotetext{
${ }^{39}$ Ibid., p. 170.
} 
be independent of religious values. In fact the figure of sex workers still have a very deep spiritual sense and have a high level of social care.

Interestingly when contemplating,sex workers have a feeling of fear of his actions which will bring havoc to himself and others; but they are also fascinated by the beauty of social reality that is full of dynamics, colors, and impresses on God's perfection. Although she was involved in it and was crushed by the patriarchal cultural system to put themselves in a position that was underestimated by the community. This fact becomes the starting point of the social existence of sex workers, because it represents itself as a fact that can be interpreted - read by sex workers - and has subjective meaning for them as a coherent world. ${ }^{40}$ However, social reality is not taken for granted as a fact by humans in every behavior that has subjective meanings in their lives. Factually, social reality is also a world that originates from their thoughts and behavior, and is maintained as a "real" fact by those thoughts and behaviors. ${ }^{41}$

If it is explored further more about the building of religious sex workers through the analysis way of Peter L. Berger, there can be a pure religious order out of the womb of the dialectical process between sex workers and social reality formed through externalization processes. Externalization from a world view that is organized and meaningful is an "anthropological necessity" that is forced by the nature of continuous biological formation of "endless" ${ }^{42}$ The awareness of sex workers is actually a criticism of the inequality of social reality that has long been built from a patriarchal system that has a dominant and exploitative tendency towards sex workers. The religious form that arises from this consciousness is a religious way that is in accordance with the rules of human rationality to deliver the nature of transcendental reality, because it does not only look at normative symbols (such as the holy book) but furthermore "reads" the ontos of humanity and the universe. Moreover, as expressed by Sachiko Murata, the correspondence and similarity of humans and the universe can reinforce the fact that humans and the universe together can represent or reach God. ${ }^{43}$

${ }^{40}$ Peter L. Berger dan Thomas Luckmann, The Social Construction of Reality: A Treatise in the Sociology of Knowledge (New York: Anchor Books, 1987), p. 19.

${ }^{41}$ Ibid., p. 20.

${ }^{42}$ Ibid.

${ }^{43}$ Murata, The Tao of Islam: Kitab Rujukan tentang Relasi Gender dalam Kosmologi dan Teologi Islam, p. 53. 
Inevitably, sex workers are able to reach self-transcendence through awareness of the "sacred". Through their consciousness, sex workers can frame life and even death with meaning, because they aware that the finitude of individual existence. With this awareness, religion is able to provide peace, tranquility and happiness to live in the world and the hereafter for humans. Similarly, sex workers in wading through life have met and felt various dynamics and problems in life. This situation is forging sex workers into humans who know "who they are" and "how they value" and "where they are in society", so they can sort and choose attitudes in front of others. From this framework, sex workers stretch ontological distance between in front of other people as sex workers (front stage) and behind others as themselves (rear stage); in other words "this is me when in front of the stage" and "here I am backstage".

On the front stage the sex workersare "blasphemed", "insulted", and "stripped of the nature of their humanity"; while on the back stage they want to be "valued with the essence of other human beings", and hopes to "run their religion without any scorn from the community". Indeed, the front stage has never been friendly to God's presence, let alone expressing the regiosity that has been oppressed by their stigma. On the back stage, they stripped themselves of religion to get peace, happiness, and love of God, because they were aware of the play they were carrying out. But strangely, there is still a very aprioristic assumption that sex workers or love peddlers are the periphery of religious actions. They are considered as people who have been outside the teachings of religion. In fact they are the same as other humans, who still need the world of faith, the mysterious God, and good deeds. However, the negative stigma that has already been inherently so strong and built in a structured manner especially by religious people - has made these people wasted structurally and culturally at the same time. ${ }^{44}$

The religiosity of sex workers is clearly a marginal diversity (peripheral religion) whose existence is sometimes not recognized by other groups. The existence of sex workers' religion is covered by a negative stigma and finally the religion of sex workers is confined in a narrow frame. Roughly speaking, the religion of sex workers is a complementary religion to other larger religions, especially religion that is embraced by the patriarchal system. All the potential of women who should be able to actualize through religion are blocked by the

${ }^{44}$ Syam, Agama Pelacur: Dramaturgi Transendental, p. 7. 
clash of religions with the patriarchal system. This limitation of sex workers is the starting point of their religious face. They tried to interpret everything about life and death as a deadline for ability (human limitations).

Therefore, religion for sex workers has a role as a symbolic universe - that is, a social fact that serves to put proportionally everything (being) in its place according to its level, and helps every human to "return to reality" of their life. ${ }^{45}$ Thus, the system of sex workers' religiosity is not as common as the religious system emblazoned in the community; it is free from religious normative symbols such as religious rituality or places of worship. Absolute reality (God) is so immersed in their soul that no one is able to understand the burst of their divine feeling.

\section{Understanding Sex Workers' Religiousity: Seeing Sex Workers' Divinity}

Rational evidence about the existence of God provides knowledge of God descriptively, while mystical experience provides knowledge of God with recognition..$^{46}$ This view provides a mapping that rationality and intuition can give a truly difference of God knowledge. It needs to be understood, the divine awareness created is able to give birth to religious experience at the deepest point of human consciousness. Jim Kanaris states, experience has a very valuable meaning; because it is a dialectic between self and transcendental reality that occurs subjective-intuitive. ${ }^{47}$ It is common if the religious experience (especially knowledge gained from experience) is said to be "revelation". When human get religious experience - following William James' view of traumatic-religious experience, he will believe that the "other reality" present is a transcendental reality (God) that has a role in his life. This condition also occurs in sex workers who interpret all sides of life as something sacred. Oftentimes sex workers express social realities that appear real versus unseen (pseudo real) and they try as much as possible at the time of solitude (backstage) living in a sacred environment with the feelings of fear, anxiety,

${ }^{45}$ Berger dan Luckmann, The Social Construction of Reality: A Treatise in the Sociology of Knowledge, p. 98.

${ }^{46}$ Daniel A. Dombrowski, A Platonic Philosophy of Religion: A Process Perspective (Albany: State University of New York Press, 2005), p. 97.

${ }^{47}$ Jim Kanaris, Bernard Lonergan's Philosophy of Religion: From Philosophy of God to Philosophy of Religious Studies (Albany: State University of New York Press, 2002), p. 24. 
and full hope that God will still be forgiven. The goal is so that they are able to throw down and get themselves into perfection in the reality of "sacred" namely as a religious human.

One example, even though the life of sex workers is frenzied and wrestles with the illegal of "lust pleasure" (religious language is called adultery, the law is haram), but when faced with the problem of meaning and purpose of sex workers' life is very different. They have an orientation that the purpose of their life wants to "meet" with God; and the meaning of their life is to achieve the purpose of life through faith and belief in God through good deeds. The paradox's life value of sex workers raises an impression, as if it is full of "actionological hypocrisy" in social reality, when they are in a space that is separated from other people (the back stage) and naked as the real self. At this time, sex workers have the opportunity to actualize themselves as self that has spirituality, self that has religiosity, and self that believes in God. This condition strengthen the theory developed by Marsha Aileen Hewitt, namely the critical theory of religion which considers religion not enough only to the ultimate goal of liberating women but needs to deliver to the nature of humanity through self-transformation. ${ }^{48}$

Based on that state, religiosity in human life is a category. ${ }^{49}$ It means in every curve of human life -as well as sex workers- has a connection with religious values. Moreover, the behavior of sex workers has clearly undermined the stigma of "the world of sex workers far from the anchor of religious values" and as if it also proves that sex workers have a unique godly process. At this position, sex workers "strip themselves" show their religiosity which is full of the value of love. It is normal if, God is in the view of a sex worker, not only as a sacred reality and only knows the facts may or may not be (black and white), but more than that it constructs as meaningful transcendental reality. Therefore, sex workers try to cultivate the reality of their humanity from profanisticstrata to sacred to God,when the social reality of sex workers morphs through the process of "refinement", then at that time humanistic and altruistic attitudes of sex worker emerged such as caring for fellow sex workers who experienced economic problems, the household and so on. This attitude is also interpreted

${ }^{48}$ Marsha Aileen Hewitt, Critical Theory of Religion: A Feminist Analysis (Minneapolis: Fortress Press, 1995).

${ }^{49}$ Warren S. Goldstein dan at.all, "Critical Theory of Religion VS Critical Religion," Critical Research on Religion 4 (2016), p. 3-7. 
by sex workers as a transactional attitude oriented to the transcendental reality between their bad attitude and how to do good among others. They believe that they will get a reward, because God will not waste all forms of good and bad human actions. William James stated that the gentle attitude of heart and love for others is the fruit of holiness. ${ }^{50}$

The religiosity of sex workers arises from the attitude of absolute dependence accompanied by total submission to God hoping to get forgiveness and guidance. It is common when sex workers do not provide space for other realities to be a place of dependence and hope except God. They hang more their hopes for God, who he has been faithful to, believes in, and he fears beyond his capacity as a dhaif creature. However, a sex worker hopes that with her sincerity in living a marginalized and exploited life, she can still be the best person in front of God. This is what Martin Riesebrodtsaid as the basic religion; that complex practices based on the premise of the superpower existence, personal and impersonal, which are generally unseen, this is the essence of religion. ${ }^{51}$ However, sex workers are still considered not bound by religious values and even placed in a very "low" position in society. It is because the community works according to its own unique principles and does not reflect the intentions of conscious individuals; ${ }^{52}$ or indeed sex workers need to be differed from normal women as what pimps do. ${ }^{53}$

Regardless of the claims of the community, the transcendence that arises in sex workers cannot be separated from the role of the nature of the identity of sex workersthemselves; namely self as a subject that orientates all profane reality in the transcendental dimension. Without this orientation, the transcendental dimension will not be able to be felt as something sacred. The process between sex workers who orient themselves to transcendental reality, and the transcendental reality itself projects itself to sex workers - borrowing the term Mircea Eliade as a hierophytic stage - is a dialectical process. When the orientation and projection meet at one point, it will be translated by sex

${ }^{50}$ William James, Perjumpaan dengan Tuhan: Ragam Pengalaman Religius Manusia, trans. oleh Gunawan Admiranto (Bandung: Mizan, 2004), p. 383.

${ }^{51}$ Martin Riesebrodt, The Promise of Salvation: A Theory of Religion (Chicago: University of Chicago Press, 2009), p. 75.

52 Doyle Paul Johnson, Teori Sosiologi Klasik dan Modern, trans. oleh Robert M.Z. Lawang (Jakarta: Gramedia, 1994), p. 214.

${ }^{53}$ Adrianna Muller, Science, Religion, and God, (Bloomington: Balbao Press, 2013), p. 45 . 
workers with the symbolic boundaries of religiosity. Therefore, the religiosity of freelance sex workers -or indeed distinguishes themselves- from the standard symbols of religion that are commonly used by society. Religion and the integrity of sex workers are very different and closely related to nuances of love, so God is described as relatively personal and immanent.

The immanent God construction is based on the value of subjectivity that goes into the religiosity experience of sex workers in the interiority form. This made a strong impression on sex workers itself by involving elements of humanity which referred to the experience of religiosity or divinity. This can be felt by anyone who at a certain point finds awareness in themselves, so that the experience can create an impression of spirituality in itself. At this point that sex workers actually construct their identity through human consciousness which is determined by their social reality. If in the theory developed by Peter L. Berger \& Thomas Luckmann, this process is a form of human behavior to build or produce themselves. ${ }^{54}$ It means the diversity of sex workers comes along with their own creations based on the meaning of social reality - reading history. It is natural that through self-awareness, sex workers build a transcendental reality in accordance with their level of knowledge and sensitivity to social reality. So that the process through its actions and interactions, sex workers create normative realities in which there are spiritual values and only personally owned, experienced by themselves and have subjective meanings. This mechanism can be likened to the social reality experienced by everyday humans socially formed. Even the community with various institutions within it is constructed, maintained and transformed through human actions and interactions themselves. ${ }^{55}$

Based on this framework, the religiosity and divinity of sex workers is the authority of their creation which needs to be recognized. Although before being expressed in its actual form, it has been ingrained in their hearts as an escape -or perhaps an internal conflict. ${ }^{56}$ This is in line with the results of Siroj Sorajjakool \& Arelis Benitez's research which found that religion was used as a form of ritual purification in dealing with prostitutes' internal conflicts. Whereas in the dimensions of divinity, sex workers before expressing it in certain forms

${ }^{54}$ Berger dan Luckmann, The Social Construction of Reality: A Treatise in the Sociology of Knowledge, p. 49.

${ }^{55}$ Ibid., p. 93.

${ }^{56}$ Siroj Sorajjakool dan Arelis Benitez, "The Role of Religion among Sex Workers in Thailand," Religions, Vol. 6, no. 4, (2015), p. 1268-76. 
such as mystical imagery or personality, the sex worker's understanding of God has been a symbol that struggles with his social reality. Sex workers can express their divine awareness in the "effectiveness" of social reality. Thus, symbols can embody a real modality that is not clear at the level of direct experience. Religious symbols can reveal the hidden side of human life, namely human life originating from "other places", from afar and are "divine", which comes from the transcendent. ${ }^{57}$ Indeed, symbolic language is more effective and far beyond the use of abstract concepts to express religiosity about God.

Another fact, sex workers in the realm of "sexuality pleasure" (coitus) that is illegal, they do not find expressions of humanity that is haikiki. In fact, theyare actually able to realize self-awareness behind the "temporary satisfaction" of men who are above their body. This awareness not only builds the normative value order in sex workers, but also raises an oppressed sense of religion. The expression of sexuality which is sacred and is a divine gift that deserves to be "grateful" should be able to deliver to God, ${ }^{58}$ but only become a profane commodity. God should be present at the "union of two souls", $\mathrm{He}$ (God) in the sex workers only becomes soft speeches and voiceless sighs. In this clear framework, sex workers' religion is an oppressed religion by male egocentric who do not want women in an egalitarian position. Whereas God who is in a sex worker a soft sigh of oppression of sex workers; where this condition confirms Mark Elmore's analysis that religion is a cultural system and spirituality is a product of capitalism that produces consumers. ${ }^{59}$

Sex workers believe that the God he feared and he hoped to become a place of dependence on him has infinity in various aspects and also the owner of the entire universe. The feeling of believing in this all-powerful reality was formed when he still did not work as a sex worker, but he felt there was no relevance between the understanding of Godhead and the pattern of life that he lived. Until when she entered prostitution, she still held strong informativenormative values about the fact of divinity. Only one that they feel that he is weak and covered by incompetence in all dimensions, so she can only complain

${ }^{57}$ M. Sastrapratedja, "Manusia dalam Bahasa Mistik-Simbolik: Mircea Eliade dan Paul Ricoeur J.," dalam Dunia, Manusia, dan Tuhan: Antologi Pencerahan Filsafat dan Teologi, ed. oleh Sudarmita dan S.P. Lili Tjahjadi (Yogyakarta: Kanisius, 2008), p. 125.

${ }^{58}$ Murata, The Tao of Islam: Kitab Rujukan tentang Relasi Gender dalam Kosmologi dan Teologi Islam, p. 260.

${ }_{59}$ Mark Elmore, Becoming Religious in a Secular Age (California: University of California Press, 2016), p. 7. 
to friends who are in the same profession and hopes God knows the condition of himself from the aspect of physical and spiritual. Until when sex worker has entered the world "the illegality of the expression of sexuality" is still convinced that "his God is God who does not leave himself and love him". Belief in God varies from one subject to divine awareness with other subjects, because of differences in the level of ability of human reason in accepting the level of divine understanding that gives rise to the concept of divine consciousness.

An important fact of this is the rise of spirituality which is only part of the reality of sex workers' humanity, but it is a holistic meaning of humanity. Therefore, sex workers are spiritual beings and the whole of the dynamics of life has a material world space that can be transformed and transcendental. Without reducing the other side, the idea that assumes spirituality is only related to one of the faculties in human beings is a form of thinking that cannot reveal holistically the profane and transcendental relations between human and God. Ibnu Arabi in this framework states, every reality of the world, or every aspect of the world, can only be understood correctly through its spiritual origin. It connects every world reality with its divine principle; and therefore need to put everything in its true place. ${ }^{60}$

Obviouslysex workers believe that God is the initial cause and ultimate goal in all forms (there are physical ontologies). It means sex workers believe in God as the eternal principle that creates everything (beings) in the universe. Sex workers' beliefs flow in his attitude that surrenders everything (physical and spiritual) only to God, so that through this concept of surrender to God, sex workers are made aware that there are no other strengths except God alone. Sex workers in this framework know the patterns (obligations) that need to be implemented and prohibited that must be shunned; meaning they know the difference between right and wrong; reward and sin; and heaven and hell. However, sex workers continue to live in the world of mucus because external factors that are beyond their capacity mainly due to economic pressure. $\mathrm{He}$, by living this life tries to mobilize his relatively deprived life to a more decent degree of life.

Therefore, sex workers hand over the right and wrong or good and bad authority to God only who knows the essence of the dynamics of his life. Sex

${ }^{60}$ Stephen Hirtenstein, Dari Keragaman ke Kesatuan Wujud: Ajaran dan Kehidupan Spiritual Syaikh al-Akbar Ibnu 'Arabi, trans. oleh Tri Wibowo (Jakarta: Murai Kencana, 2001), p. 9. 
workers also have the desire to increase self-esteem (dignity and prestige) to not be continuous in the prostitution pool. They consider that they are not different from other human who have the desire to achieve happiness in the world or in the hereafter. Although in fact they did not want to enter this world of prostitution which often exploited and dominated the nature of his humanity. Ordinarily, sex workers need superior, powerful, and respected realities or a supernatural, extra ordinate, not easily be forgotten and very important in interpreting their lives. Religion in this framework becomes an institution that serves to accommodate the dynamic of the sacredness of relations between sex workers and the reality of God.

The fundamental function of the religion for sex workers social existence is not only at that level, but it is also able to correlate the constructs of absurd and chaotic empirical realities with sacred and transcendental realities. In this framework, Peter L. Berger states, religion is the most effective form of legitimacy because it is able to connect the vulnerable reality construction of empirical societies with full reality. ${ }^{61}$ However, there are things that need to be watched out for religious phenomena (obedience to God) in the social realm that are sometimes able to blind the eyes of the heart and common sense of the followers of religion. Heavenly promises can make someone willing to die which in the name of God has the right to oppress and kill others who are considered infidels and enemies of God. ${ }^{62}$

Normatively, sex workers believe in a supreme, gentle, and nondiscriminatory God towards His creatures. They constructed a pattern of understanding of the divinity of beliefs about the sacred or sacred. Thus, its divinity ratified the psychic of sex workers to transform themselves from the strata of consciousness to other consciousness's which have different qualities from the previous consciousness such as from human consciousness to the divine. If so, religion for sex workers is not only a matter of "believe" (to believe) an sich, but how to "entrust" (to trush) to the sacred. Such religion is a basic human need, because it is a medium for his existential defense of his activities in his world. ${ }^{63}$

${ }^{61}$ Berger dan Luckmann, The Social Construction of Reality: A Treatise in the Sociology of Knowledge, p. 32.

${ }^{62}$ Abdul Munir Mulkhan, Satu Tuhan Seribu Tafsir (Yogyakarta: Kanisius, 2007), p. 136.

Berger, p. 17.

${ }^{63}$ Noor, Agama Sebagai Universum Simbolik: Kajian Filosofis Pemikiran Peter L. 
Information that serves as a guide to religiosity and divinity of sex workers is their holy book. This is to build the concept of divinity in themselves as the basis of the religious beliefs and beliefs of sex workers. On the other hand, the social experience of sex workers who continue to struggle with other realities in the everyday world is a form of experience full of the meaning of religion or godliness. This struggle made the sex workers aware of their essence, even though she was not immediately able to release herself from the structuralsystemic snare of the sex workers' life.

It needs to be realized that the problem of prostitution is a form of structural problems and aspects such as economics, social, cultural, and even religious interconnection in constructing a basic understanding of sex workers to find the essence of the problem's roots. However, the risky fact is that the phenomenon of sex workers in social reality is understood as a problematic fact of morality, so that unconsciously the perception of morality implies the attitude of blaming sex workers as victims of these structural problems. At this level the position of sex workers as victims is increasingly oppressed and is crushed by facts that are reductively constructed.

\section{E. Conclusion}

Religiosity and divinity of sex workers have unique characteristics and are very far from the visible form. The diversity of sex workers is born from the awareness of their position in the valley of "sexual pleasure" without legality and causes him anxiety, anxiety, and longing for the presence of God in his life. This awareness is formed from the results of dialogue between sex workers and social reality to bias the conception and perception of God. Religion is practiced apart from religious normative symbols such as religious rituality or places of worship. God is immersed tightly in their soul and They are present in the most subjective and impersonal form in the sex workers. Based on this, the community needs to have wisdom to position sex workers on the stage of social reality. On the one hand, the community also needs to open itself to the social reality - sex workers - to encourage the growth and development of religious and religious value relations between the front stage and the rear stage. [.] 


\section{REFERENCES}

Abdullah, M. Amin. Islamic Studies di Perguruan Tinggi: Pendekatan IntegratifInterkonektif,. Yogyakarta: Pustaka Pelajar, 2006.

Acharya, Arun Kumar. "Impact of Cultural and Religious Practices of Prostitution on the Trafficking of Women in India." Trayectorias, 3334, 14, no. juli-juni (2011): 95-114.

Arnold, Johann Christoph. Sex, God \& Marriage. Farmington: The Bruderhof Foundation, Inc., 2002.

Asy’arie, Musa. Filsafat Islam: Sunnah Nabi dalam Berpikir. Yogyakarta: LESFI, 2001.

Bartley, Paula. Prostitution: Prevention and Reform in England, 1860-1914. London: Routledge, 2000.

Berger, Peter L., dan Thomas Luckmann. The Social Construction of Reality: A Treatise in the Sociology of Knowledge. New York: Anchor Books, 1987.

Broude, Gwen J. "Sexual Attitudes and Practice." Dalam Encyclopedia of Sex and Gender: Men and Women in the World's Cultures, disunting oleh Carol R. Ember dan Melvin Ember, 177. New York: Plenum Publishers, 2003.

DiCenso, James J. The Other Freud: Religion, Culture and Psychoanalysis. London: Routledge, 1999.

Dombrowski, Daniel A. A Platonic Philosophy of Religion: A Process Perspective. Albany: State University of New York Press, 2005.

Eliade, Mircea. Sakral dan Profan. Diterjemahkan oleh Nuwanto. Yogyakarta: Fajar Pustaka Baru, 2002.

- - C. Sakral dan Profan, t.t.

Ellwood, Robert S., dan Gregory D. Alles. The Encyclopedia of World Religions,. New York: Facts On File, Inc., 2007.

Elmore, Mark. Becoming Religious in a Secular Age. California: University of California Press, 2016.

Erfan, Mohammad. Menalar Tuhan Filosof Islam: Kajian Kritis Konsep Teologi Ibnu Rusyd. Yogyakarta: Kerjasama LK3 \& Aswaja Pressindo, 2011. 
Fauzi, Muhammad Latif. "Religious Symbolism and Democracy Encauntered: A case of Prostitution Bylaw of Bantul." al-Jami'ah, 1, 50 (2012): 87118.

Garton, Stephen. Histories of Sexuality: Antiquity to Sexual Revolution. London: Equinox Publishing Ltd., 2006.

Goldstein, Warren S., dan at.all. "Critical Theory of Religion VS Critical Religion." Critical Research on Religion 4 (2016): 3-7.

Haviland, William A. Antropologi. Diterjemahkan oleh RG. Soekadijo. Jakarta: Erlangga, 1993.

Hewitt, Marsha Aileen. Critical Theory of Religion: A Feminist Analysis. Minneapolis: Fortress Press, 1995.

Hick, John H. Philosophy of Religion. New Jersey: Prentice-Hall, Inc., 1990.

Hirtenstein, Stephen. Dari Keragaman ke Kesatuan Wujud: Ajaran dan Kehidupan Spiritual Syaikh al-Akbar Ibnu 'Arabi. Diterjemahkan oleh Tri Wibowo. Jakarta: Murai Kencana, 2001.

Ihsan, Soffa. In The Name of Sex: Santri, Dunia Kelamin, dan Kitab Kuning. (Surabaya: JP Books, 2004.

Izutsu, Toshihiko. Relasi Tuhan dan Manusia: Pendekatan Semantik terhadap al-Qur'an. Diterjemahkan oleh Agus Fahri Husein. Yogyakarta: Tiara Wacana Yogya, 2003.

James, William. Perjumpaan dengan Tuhan: Ragam Pengalaman Religius Manusia. Diterjemahkan oleh Gunawan Admiranto. Bandung: Mizan, 2004.

Johnson, Doyle Paul. Teori Sosiologi Klasik dan Modern. Diterjemahkan oleh Robert M.Z. Lawang. Jakarta: Gramedia, 1994.

Kanaris, Jim. Bernard Lonergan's Philosophy of Religion: From Philosophy of God to Philosophy of Religious Studies. Albany: State University of New York Press, 2002.

Macedo, Edir. The Faith of Abraham: Self-Denial, Sacrifice, Trust and Total Surrender. Rio de Janeiro, 2018.

Meister, Chad. Introducing Philosophy of Religion,. London: Routledge, 2009.

Melissa Hope Ditmore, ed. Melissa Hope Ditmore (Edit.), Encyclopedia of Prostitution and Sex Work, Vol. 2 (O-Z), (London: Greenwood Press, 2006), 388. Vol. 2. O-Z vol. London: Greenwood Press, 2006. 
Moury, Marissa. “London's Bridewell: Violence, Prostitution, and Questions of Evidence." Dalam Violence, Politics, and Gender in Early Modern England, disunting oleh Joseph P. Ward, 217. New York: Palgrave Macmillan, 2008.

Mu'arif. Monoteisme Samawi Autentik: Dialektika Iman dalam Sejarah Peradaban Yahudi, Kristen, dan Islam, ; Yogyakarta: IRCiSoD, 2018.

Mulkhan, Abdul Munir. Satu Tuhan Seribu Tafsir. Yogyakarta: Kanisius, 2007. Muller, Adrianna. Science, Religion, and God,. Bloomington: Balbao Press, 2013.

Murata, Sachiko. The Tao of Islam, t.t.

- - - The Tao of Islam: Kitab Rujukan tentang Relasi Gender dalam Kosmologi dan Teologi Islam. Diterjemahkan oleh Rahmani Astuti dan M.S. Nasrullah. (Bandung: Mizan, 2000.

Noor, Irfan. Agama Sebagai Universum Simbolik: Kajian Filosofis Pemikiran Peter L. Berger. Yogyakarta: Pustaka Prisma, 2011.

Otto, Rudolf. The Idea of The Holy. England: Penguin Books, 1989.

Pojman, Louis P., dan Michael Rea, ed. Philosophy of Religion: An Anthology,. Canada: Thomson Wadsworth, 2008.

Poythress, Vern S. Reading The Word of God In The Presence of God: A Handbook For Biblical Interpretation,. Illonis: Crossway, 2006.

Rahardjo, M. Dawam. Ensiklopedi al-Qur'an: Tafsir Sosial Berdasarkan KonsepKonsep Kunci. Jakarta: Paramadina, 2002.

Ratih, Bene. "Perempuan dan Teater." Dalam Teori-Teori Kebudayaan, disunting oleh Mudji Sutrisno dan Hendar Putranto. Yogyakarta: Kanisius, 2005.

Ray, Darrel W. Sex \& God: How Religion Distorts Sexuality. Kansas: IPC Press, 2012.

Riesebrodt, Martin. The Promise of Salvation: A Theory of Religion. Chicago: University of Chicago Press, 2009.

Robert, Tyler T. Spiritualitas Postreligius: Eksplorasi Hermeneutis Transfigurasi Agama dalam Praksis Fiilsafat Nietzsche. Diterjemahkan oleh M. Khatarina. Yogyakarta: Qalam, 2002.

Saeed, Abdullah. Islamic Thought: An Introduction. London: Routledge, 2006. Sastrapratedja, M. "Manusia dalam Bahasa Mistik-Simbolik: Mircea Eliade dan Paul Ricoeur J." Dalam Dunia, Manusia, dan Tuhan: Antologi 
Pencerahan Filsafat dan Teologi, disunting oleh Sudarmita dan S.P. Lili Tjahjadi. Yogyakarta: Kanisius, 2008.

Shihab, M. Quraish. Wawasan al-Qur'an: Tafsir Maudhu'i atas Pelbagai Persoalan Umat. Bandung: Mizan, 2004.

Sorajjakool, Siroj, dan Arelis Benitez. "The Role of Religion among Sex Workers in Thailand." Journal Religions, 4, 6, no. Oktober (2015): 1268-76.

Syam, Nur. Agama Pelacur: Dramaturgi Transendental. Yogyakarta: LKiS, 2010.

Thompson, Harold. Abraham: from Faith to Faith. Bloomington: WestBow Press, 2017.

VanArragon, Raymond J. Key Terms in Philosophy of Religion. London: Continuum, 2010.

Weber, Max. The Sociology of Religion. Diterjemahkan oleh Ephraim Fischoff. Boston: Beacon Press, 1964.

Whitehead, Alfred North. Mencari Tuhan Sepanjang Zaman: Dari AgamaKesukuan hingga Agama-Universal. Diterjemahkan oleh Alois Agus Nugroho. Bandung: Mizan, 2009.

Zerubavel, Eviatar. “The Five Pillars of Essentialism: Reification and the Social Construction of an Objective Reality.' Jurnal Brintish Sociological Association, 1, 10, no. Maret (2016): 69-76. 